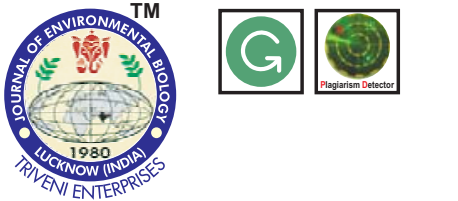

DOI : http://doi.org/10.22438/jeb/38/6/MRN-356

\title{
Plankton community characteristics of natural and man-made tropical lakes
}

ISSN: 0254-8704 (Print) ISSN: 2394-0379 (Online) CODEN: JEBIDP

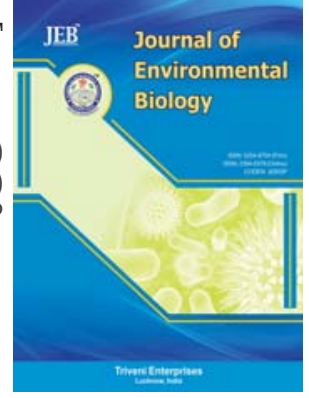

Authors Info

Z. Sharip ${ }^{1 *}$ and F. Md. Yusoff ${ }^{2}$

${ }^{1}$ Lake Research Unit, Research Centre for Water Quality and Environment, National Hydraulic Research Institute of Malaysia, Lot 5377, Jalan Putra Permai 43300 Seri Kembangan, Selangor Malaysia

${ }^{2}$ Laboratory of Marine Biotechnology, Institute of Bioscience, University Putra Malaysia, 43400 UPM, Serdang, Selangor, Malaysia

${ }^{*}$ Corresponding Author Email zati@nahrim.gov.my

Key words

Lentic ecosystems

Multivariate analyses

Phytoplankton community

Tropical lakes

Publication Info

Paper received : 21.05 .2016

Revised received : 04.11 .2016

Re-revised received : 23.04 .2017

Accepted : 22.05.2017

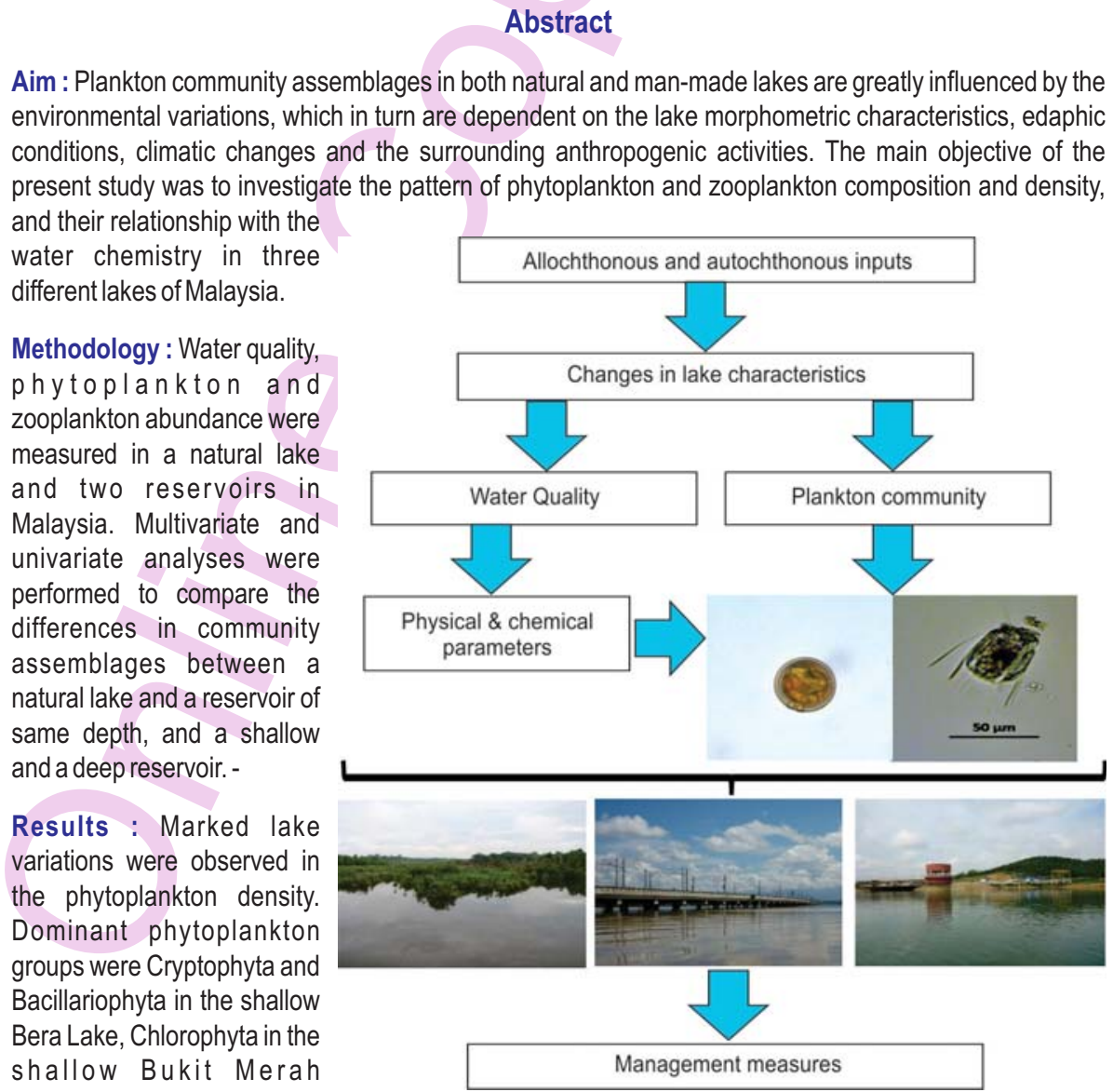

Reservoir and Euglenophyta

and Chlorophyta in the deeper Durian Tunggal reservoir. Both man-made lakes had significantly higher $(\mathrm{P}<$ 0.05) plankton densities compared to the natural lake. The shallower Bukit Merah Reservoir had higher phytoplankton density compared to the deeper Durian Tunggal Reservoir. Dissolved oxygen and pH levels were correlated to the phytoplankton and zooplankton communities in the Bera floodplain, whilst nutrient and chlorophyll-a concentrations were important factors affecting the phytoplankton and zooplankton assemblages, respectively,in the Durian Tunggal and Bukit Merah reservoirs.

Interpretation : Plankton community in shallow tropical lakes have different characteristics and composition compared to the deeper ones, and thus requiring different management measures. 


\section{Introduction}

Biological communities such as phytoplankton and zooplankton are important components in lakes constituting the basis of the food web that shape the ecological structure and function of water bodies. The assemblages of these phytoplankton and zooplankton communities are dependent on the abiotic factors such as light and mixing, which are influenced by the nutrient, meteorological-climate and water level variations (Barone and Flores, 1994; Wetzel, 2001). Alteration in light regime and nutrient contents in a waterbody leads to a shift in phytoplankton assemblages due to differences in species physiological and morphological adaptation (Reynolds, 1998). Eutrophic or nutrient-rich lakes are usually dominated by large colony forming cyanobacteria whilst mesotrophic lakes are dominated by large colonies of chlorophytes (Naselli-Flores and Barone, 2000).

In addition to nutrients and light regimes, water body type, size, depth, age, geographical location and habitat connectivity are among other factors that contribute to the variation in plankton community assemblages (De Bie et al., 2008; Merrix-Jones et al., 2013). De Bie et al. (2008) reported that lakes have the highest mean diversity and number of species of zooplankton namely cladoceran communities, compared to other aquatic ecosystems probably due to the favourable conditions associated with the lentic characteristics. In fact, Dodson et al. (2007) reported that zooplankton structures were shaped by the size of the lake. Small water bodies were reported to have higher cladoceran abundance and richness than the larger ones (De Bie et al., 2008), mainly due to higher availability of nutrients in shallower water bodies compared to the deeper ones. A decrease in phytoplankton and zooplankton densities in lakes in relation to depth are well documented worldwide. Natural lakes differ from man-made lake in terms of connectivity and water level regulation that may affect the light regime and nutrient flushing, which subsequently affect the biological community assemblages. In temperate lakes, Naselli-Flores and Barone (2000) noted that variation of surface mixed layer depth/euphotic depth ratio could trigger the shift in biological assemblage in man-made lakes compared to the natural lakes which were more hydrologically stable. Deeper and cooler zooplankton species such as Acanthocyclops spp. and Cyclops spp. have been frequently detected in natural lakes (Merrix-Jones et al.,2013). Drivers of zooplankton composition in temperate lakes include depth, conductivity, salinity and productivity (Dodson et al., 2009; MerrixJones et al., 2013).

In man-made lakes where water levels are regulated, increase in water level reduces the zooplankton density and biomass, and decreases chlorophyll-a concentration, resulting from hydraulic changes and the associated increased in suspended sediments (Mac Donagh et al., 2009). Low water level and high temperature during summers, contribute to higher total phosphorus, dissolved inorganic nitrogen, soluble reactive phosphate ratio and chlorophyll-a, subsequently increasing the dominance of cyanobacterial biomass in Estonian lakes (Haldna et al., 2008). In contrast, increasing biomass of diatoms and decreasing biomasses of cyanobacteria were observed during lower water levels in a deep high-altitude tropical reservoir (Valeriano-Riveros et al., 2014). The influence of age on zooplankton assemblages were observed to be apparent in manmade lakes with pristine watersheds (Alfonso et al., 2010) whereas, the effect of age on zooplankton composition in artificial lakes with heavily disturbed catchment may be compounded by the anthropogenic activities in watersheds (Alfonso et al., 2010). Differences in plankton assemblages between natural and manmade lakes in tropical region are limited.

In view of the above, the present study was carried out to investigate the pattern of plankton composition and density, and their relationship to water chemistry in three different lakes in Malaysia to enable a better understanding of plankton community structure in natural and man-made lakes at different depths.

\section{Materials and Methods}

Three lakes in Peninsular Malaysia namely Bera lake, Pahang, Bukit Merah reservoir, Perak and Durian Tunggal reservoir, Melaka were selected as study area (Fig. 1). Bera lake is a natural floodplain lake with a total surface area of $6 \mathrm{~km}^{2}$, mean depth of $\sim 2.8 \mathrm{~m}$. It is a dystrophic wetland designated as an important RAMSAR site, due to its diverse freshwater biodiversity of many endemic species. The water body is known as the largest and among the oldest freshwater lake in the country with organic and peat deposits originating 4500-5500 years ago (Morley, 1981). Bera lake is largely fed by Tembagau river throughout the year and acts as a discharge outlet to the Pahang river, which becomes a major inflow into the lake during the wet season. Bukit Merah reservoir is one of the oldest artificial lakes in Malaysia created in 1906 for irrigation and flood mitigation purposes. In addition, the reservoir also stores water for drinking and domestic purposes, and a sanctuary for the endemic Scleropages formosus of the golden arowana variety. It is a large lentic water body (surface area of $33 \mathrm{~km}^{2}$ ) but very shallow (mean depth of $\sim 2.5 \mathrm{~m}$ ) and is mostly fed by Kurau river and Merah river, and discharged into Terusan and Selingsing dams. Durian Tunggal reservoir is an important reservoir that was created in 1974 for water supply. It is the youngest lake created $(<50 \mathrm{yr})$ compared to Bera lake $>4500$ $\mathrm{yr})$ and Bukit Merah reservoir (>100 yr) for this study. The reservoir has a surface area of $5.8 \mathrm{~km}^{2}$ and mean depth of $\sim 6 \mathrm{~m}$. The lake is heavily regulated and dependent on inter-water transfer scheme namely water pumping from Muar River in Johor.

The water and plankton samples were collected from three lakes during wet season (December) and dry season (May). Sites were selected both in the pelagic and littoral areas. Water quality was estimated based on in situ measurements using a multi-parameter probe, YSI 6600 (YSI Inc., Yellow Springs. OH, USA) and laboratory analyses of water samples collected from each lake. Water samples were collected using a Van Dorn sampler and was preserved in cooler boxes at $4{ }^{\circ} \mathrm{C}$ and 
transported to laboratory for analysis of chlorophyll-a (Chla), nitrate $\left(\mathrm{NO}_{3}-\mathrm{N}\right)$, soluble reactive phosphorus $\left(\mathrm{PO}_{4}-\mathrm{P}\right)$, dissolved organic carbon (DOC), total suspended solids (TSS), and total phosphorus (TP). Measurements were performed at three depths in the pelagic region (depth exceeded $2 \mathrm{~m}$ ) and measured at $0.5 \mathrm{~m}$ near littoral zone.

For phytoplankton, one litre of lake water samples were collected below the surface of water column, mid-depth and near bottom of the lake and samples were fixed in situ with Lugol's iodine to achieve $1 \%$ final solution. The samples were identified and counted under an inverted microscope to the lowest taxa possible. Densities were calculated in terms of number of cells $/ \mathrm{ml}$ in the sample. Zooplankton samples were collected in vertical hauls using a $63 \mu \mathrm{m}$ plankton net by lowering the net to near lake bottom to the surface. The samples were poured into $500 \mathrm{ml}$ bottles and fixed in situ with buffered formalin to provide $5 \%$ final solution. Samples were collected in each site with at least two replicates for each season. The samples were identified and counted to the lowest taxa using an inverted microscope and a compound microscope. Densities were calculated to the number of individuals per litre of water sample.

All analyses in the laboratory were based on standard methods for the examination of water and wastewater (APHA, 2012): Chla-fluorometric method; $\mathrm{NO}_{3}-\mathrm{N}$ - automated hydrazine method; $\mathrm{NH}_{3} \mathrm{~N}$ - automated phenate method; DOC - wet oxidation method; TSS - gravimetric technique; $\mathrm{PO}_{4}$ - molybdate method; TP - persulphate digestion and automated ascorbic acid reduction method.

Environmental variables were transformed and analysed using principal component analysis (PCA). Univariate analysis was performed to examine the differences in three lakes. Plankton communities were examined based on nonmultidimensional scaling (NMDS) and cluster analysis to detect similarities/differences of the plankton assemblages as described in Sharip et al., (2012). PERMANOVA was used to estimate the components of variation in phytoplankton and zooplankton community compositions at the spatial scale of lake and depth, while principal coordinate analysis ( $\mathrm{PCOA}$ ) was used to correlate environmental variables with the ordination axes based on Pearson Correlation (Anderson and Willis, 2003; Sharip et al., 2012). T-test and SIMPER were used to analyse the differences in phytoplankton and zooplankton assemblages between the following: the natural and shallower man-made lake and the shallower and deeper man-made lakes. All multivariate analyses were performed using PRIMER 6 (Plymouth Marine Laboratory, Plymouth, UK), while univariates were analysed using SPSS. The alpha level of significance was set at 0.05 .

\section{Results and Discussion}

Durian Tunggal reservoir had the highest clarity followed by Bera and Bukit Merah lakes (Table 1). Surface DO levels were lowest in Bera lake whilst chlorophyll-a concentrations were highest in Bukit Merah reservoir. Mean PCA of the environmental variables, derived by employing Euclidean distance, indicated marked differences between lakes. The first three eigenvalues of the principal components explained $65.1 \%$ of the variance; the first component corresponded to $37 \%$ variance and the second component explained $17 \%$ of the variance (Fig. 2). The first component along axis 1 was correlated with transparency, nitrate, phosphate and conductivity; the component along axis 2 was correlated with chlorophyll-a, DO, pH and DOC. Univariate analysis indicated significant differences in water quality between

Table 1: Mean variation of environmental variables between lakes.

\begin{tabular}{|c|c|c|c|c|c|c|}
\hline \multirow[b]{2}{*}{ Season } & \multicolumn{2}{|c|}{ Bera } & \multicolumn{2}{|l|}{ Bukit Merah } & \multicolumn{2}{|c|}{ Durian Tunggal } \\
\hline & Wet & Dry & Wet & Dry & Wet & Dry \\
\hline Temperature $\left({ }^{\circ} \mathrm{C}\right)$ & $27.7 \pm 0.5^{\mathrm{a}}$ & $30.2 \pm 0.4^{b}$ & $29.6 \pm 0.8^{c}$ & $29.8 \pm 0.8^{c}$ & $29.2 \pm 0.6^{e}$ & $30.7 \pm 0.6^{\mathrm{e}}$ \\
\hline Conductivity $\left(\mu \mathrm{S} \mathrm{cm}^{-1}\right)$ & $50.2 \pm 1.6^{\mathrm{a}}$ & $56.9 \pm 1.7^{b}$ & $23.4 \pm 4.1^{c}$ & $30.8 \pm 5.2^{d}$ & $87.4 \pm 2.3^{e}$ & $144.4 \pm 4.1^{\dagger}$ \\
\hline $\mathrm{pH}$ & $4.62 \pm 0.43^{\mathrm{a}}$ & $5.43 \pm 0.42^{b}$ & $6.32 \pm 0.38^{c}$ & $6.50 \pm 0.94^{c}$ & $6.69 \pm 0.41^{\mathrm{e}}$ & $6.38 \pm 0.30^{\circ}$ \\
\hline Dissolved oxygen $\left(\mathrm{mg} \mathrm{l}^{-1}\right)$ & $3.02 \pm 0.74^{a}$ & $3.19 \pm 1.07^{a}$ & $6.83 \pm 0.75^{c}$ & $6.98 \pm 0.65^{c}$ & $5.29 \pm 2.47^{e}$ & $5.29 \pm 1.92^{\circ}$ \\
\hline Depth $(m)$ & $5.9 \pm 1.7^{\mathrm{a}}$ & $5.0 \pm 1.6^{\mathrm{a}}$ & $2.8 \pm 0.5^{c}$ & $2.5 \pm 0.5^{c}$ & $8.7 \pm 4.4^{\mathrm{e}}$ & $6.9 \pm 4.3^{\mathrm{e}}$ \\
\hline Secchi disk transparency (m) & $0.8 \pm 0.3^{\mathrm{a}}$ & $1.4 \pm 0.2^{b}$ & $0.8 \pm 0.2^{c}$ & $0.6 \pm 0.2^{c}$ & $2.4 \pm 0.4^{\mathrm{e}}$ & $2.4 \pm 0.3^{e}$ \\
\hline Turbidity (NTU) & $22.1 \pm 11.1^{\mathrm{a}}$ & $2.7 \pm 0.7^{b}$ & $12.9 \pm 19.3^{c}$ & $20.6 \pm 12.9^{d}$ & $21.9 \pm 16.8^{\mathrm{e}}$ & $3.1 \pm 5.2 b^{f}$ \\
\hline Dissolved organic carbon $\left(\mathrm{mg} \mathrm{l}^{-1}\right)$ & $9.1 \pm 0.2^{\mathrm{a}}$ & $10.0 \pm 1.8^{\mathrm{a}}$ & $4.5 \pm 1.0^{c}$ & $4.9 \pm 0.9^{c}$ & $3.7 \pm 0.5^{\mathrm{e}}$ & $3.1 \pm 0.1^{\dagger}$ \\
\hline Total phosphorus $\left(\mathrm{mg} \mathrm{l}^{-1}\right)$ & $0.072 \pm 0.179^{\mathrm{a}}$ & $0.046 \pm 0.019^{a}$ & $0.076 \pm 0.174^{c}$ & $0.026 \pm 0.027^{c}$ & $0.016 \pm 0.009^{e}$ & $0.069 \pm 0.091^{\mathrm{e}}$ \\
\hline $\mathrm{PO}_{4}-\mathrm{P}(\mathrm{mg} \mathrm{l}-1)$ & $0.002 \pm 0.002^{\mathrm{a}}$ & $0.017 \pm 0.006^{b}$ & $N D^{c}$ & $0.006 \pm 0.009^{c}$ & $0.013 \pm 0.004^{e}$ & $0.026 \pm 0.004^{f}$ \\
\hline Chlorophyll-a $\left(\mu \mathrm{g} \mathrm{l}{ }^{-1}\right)$ & $2.09 \pm 2.24^{\mathrm{a}}$ & $3.29 \pm 4.96^{\mathrm{a}}$ & $12.89 \pm 4.83^{\mathrm{c}}$ & $10.2 \pm 9.8^{c}$ & $5.59 \pm 2.10^{\circ}$ & $3.01 \pm 3.23^{e}$ \\
\hline $\mathrm{NH}_{4}-\mathrm{N}\left(\mathrm{mg} \mathrm{l}^{-1}\right)$ & $0.017 \pm 0.037^{\mathrm{a}}$ & $0.189 \pm 0.549^{\mathrm{a}}$ & $0.023 \pm 0.049^{c}$ & $0.099 \pm 0.114^{d}$ & $\mathrm{ND}^{\mathrm{e}}$ & $0.126 \pm 0.079^{f}$ \\
\hline $\mathrm{NO}_{3}-\mathrm{N}\left(\mathrm{mg} \mathrm{l}^{-1}\right)$ & $0.155 \pm 0.04^{a}$ & $N D^{b}$ & $0.034 \pm 0.038^{c}$ & $0.060 \pm 0.110^{\circ}$ & $1.325 \pm 0.323^{\mathrm{e}}$ & $1.658 \pm 0.982^{\mathrm{e}}$ \\
\hline $\mathrm{TSS}\left(\mathrm{mg} \mathrm{l}^{-1}\right)$ & $9.36 \pm 20.15^{\mathrm{a}}$ & $6.45 \pm 10.81^{\mathrm{a}}$ & $5.09 \pm 2.58^{c}$ & $9.36 \pm 7.07^{\circ}$ & $2.27 \pm 2.68^{\mathrm{e}}$ & $1.45 \pm 0.69^{\circ}$ \\
\hline TSI (Chla) & 37.8 & 42.2 & 55.7 & 53.4 & 47.4 & 41.4 \\
\hline
\end{tabular}

Values are mean $\pm S D(n=11)$; Values (in rows) with different letters superscripts are significantly different $(P<0.05)$; ND- non detectible 


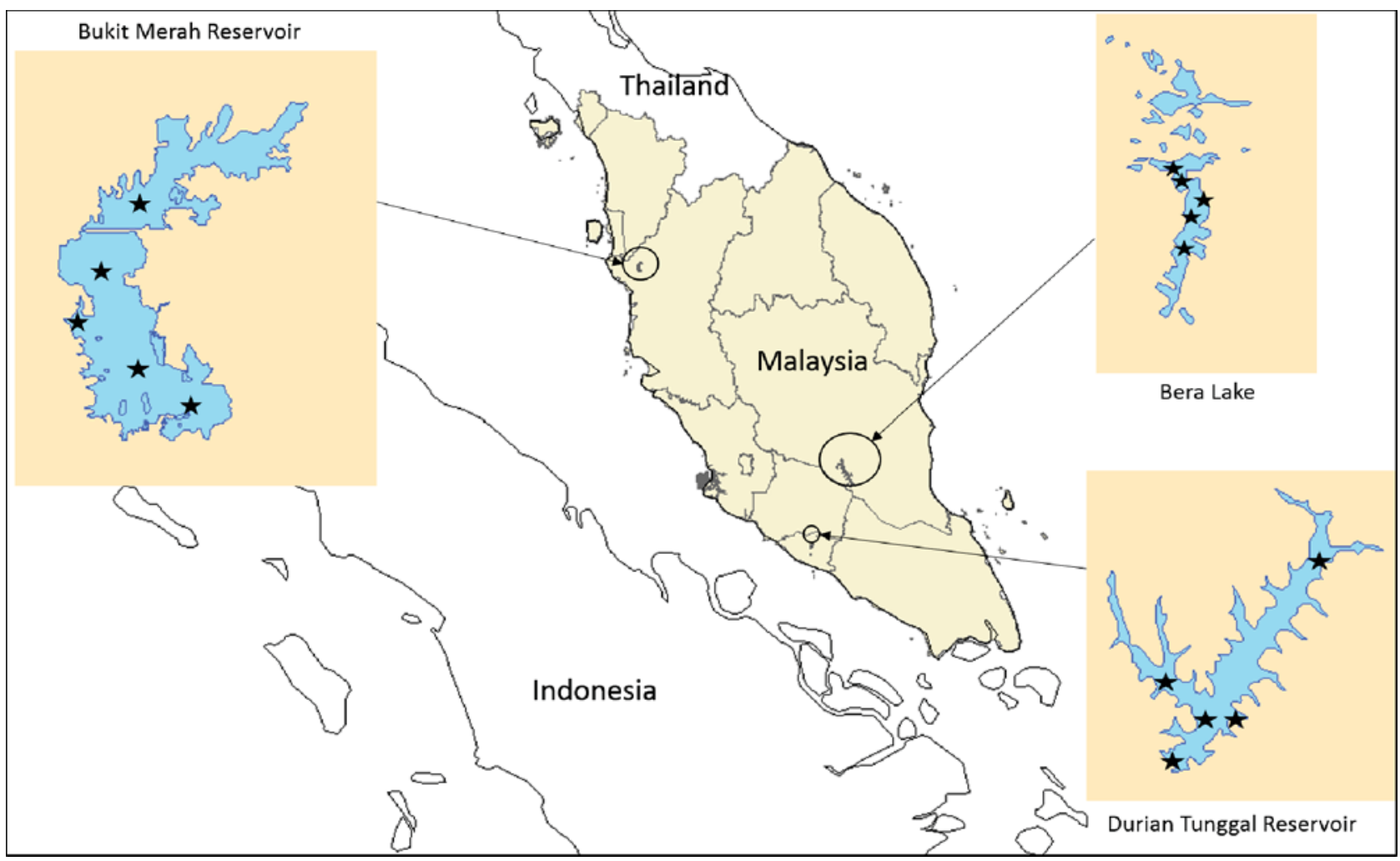

Fig. 1 : Location of study areas in various lakes and the sampling locations (stars)

lakes $f(54)=44.96, P<0.001$. Significant differences between lakes were observed in terms of temperature, specific conductivity, pH, dissolved oxygen, depth, transparency, chlorophyll-a, nitrate, phosphate and TSS. These differences showed significant impacts on phytoplankton communities.

The t-test for environmental variables between the natural Bera lake and the created Bukit Merah reservoir indicated marked differences between lakes in terms of temperature, specific conductivity, pH, chlorophyll-a, DO, salinity and DOC $(\mathrm{P}<0.05)$. T-test analysis for Bukit Merah and Durian Tunggal reservoirs showed marked differences were observed in temperature, specific conductivity, salinity, DO, transparency, Chla, TSS, $\mathrm{NO}_{3} \mathrm{~N}, \mathrm{PO}_{4}-\mathrm{P}(\mathrm{P}<0.001), \mathrm{pH}$ and turbidity $(P<0.05)$. Bukit Merah reservoir had higher Chla, DO, TSS and turbidity whilst Durian Tunggal reservoir has higher conductivity, salinity, transparency and nitrate concentrations. Bera lake and Durian Tunggal reservoir had higher turbidity during wet period possibly due to influxes of turbid water from Bera river and Muar river, respectively as our qualitative observation.In Durian Tunggal reservoir, water in the lake was characterized by lower levels of nutrients including ammonium and higher levels of turbidity during the wet season and higher conductivity, and ammonium levels during dry season. Both Bera and Durian Tunggal could be categorized as mesotrophic during the two study periods.

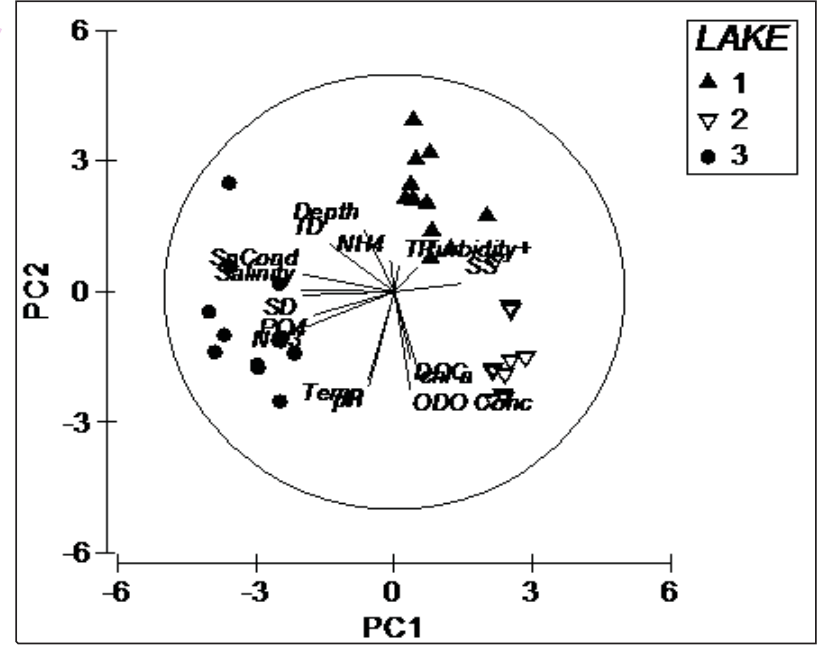

Fig. 2 : PCA biplots of mean values of the environmental variables in different lakes and reservoirs. Number indicates lake; 1 - Bera, 2 Durian Tunggal; 3 - Bukit Merah

Phytoplankton assemblages were clearly different between Bera lake and Durian Tunggal reservoir (Fig. 3). In Bera lake, Cryptophyta and Cholorophyta were the dominant groups during the wet season and dry seasons. Bacillariophyceae and 


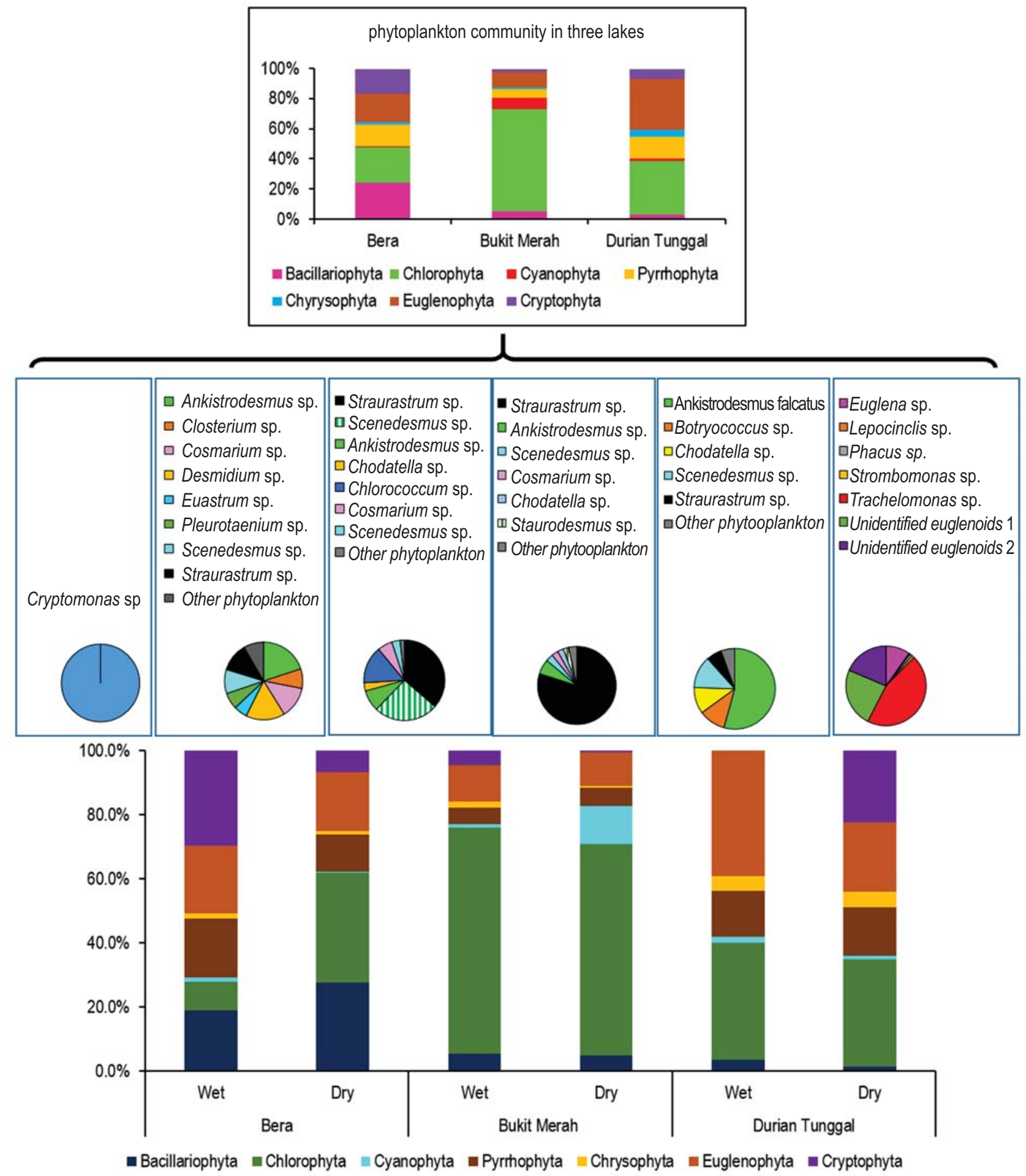

Fig. 3 : Phytoplankton group assemblages in different lakes (bars) and dominant species composition (pie charts)

Chlorophyta density increased, while Cryptophyta, Pyrrophyta and Euglenophyta decreased significantly from wet to dry season. Dominant species were Cryptomonas sp., Peridinium sp. and Trachelomonas sp. The dominance of Cryptophyta and Bacillariophyceae in Bera Lake is consistent with existing literature findings regarding natural lakes (Naselli-Flores and Barone, 2000). In an earlier study on Bera Lake in the 1970s, Chlorophyta was reported to be more dominant, contributing $50 \%$ of the average species composition, followed by Bacillariophyceae (Furtado and Mori, 1982). Seasonal patterns of 

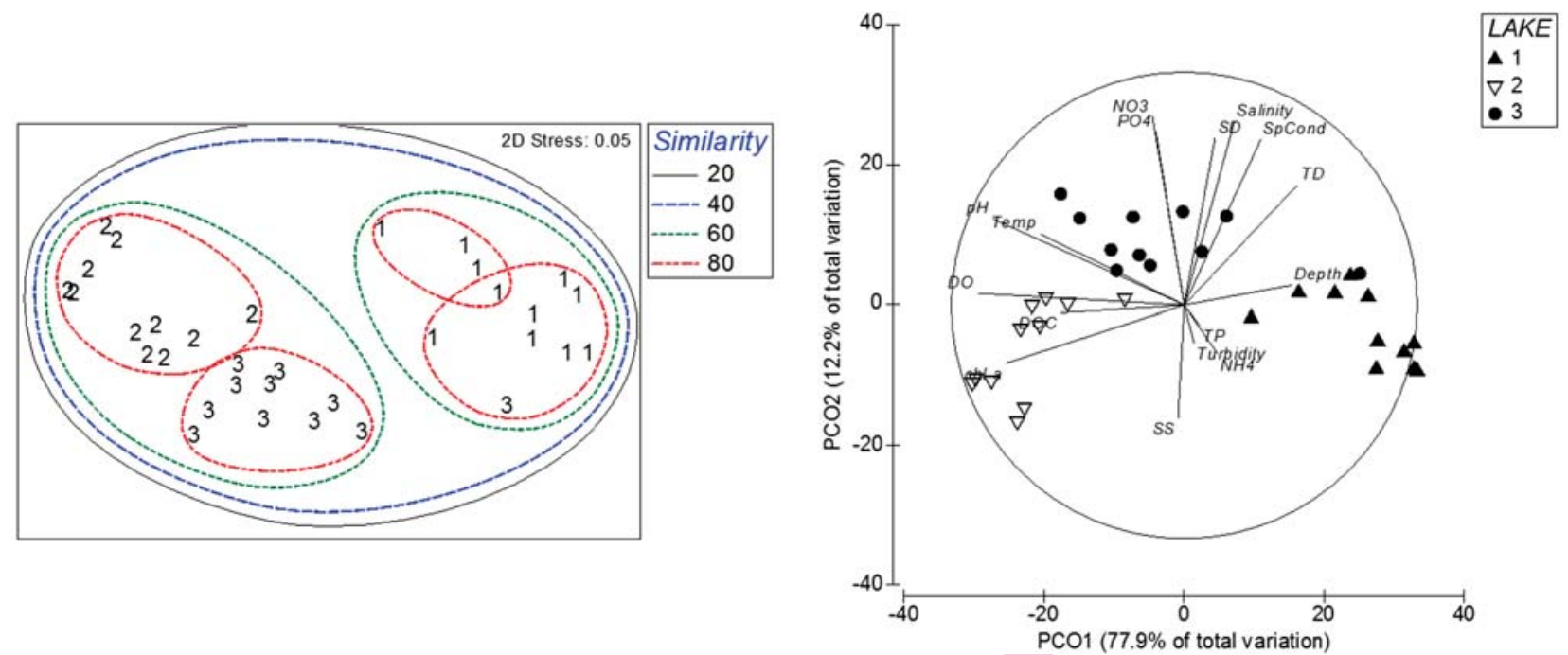

Fig. 4 : NMDS and PCoA biplots of phytoplankton assemblages in lacustrine zones. Number indicates lake; 1 - Bera, 2 - Bukit Merah; 3 Durian Tunggal

Bacillariophyceae in this lake were consistent with the earlier findings, where higher densities were reported during April to June, whilst a reduction in Cryptophyta could be related to changes in water level. Water level influenced the dominance of Cryptophyta in Peipsi Lake, Estonia (Haldna et al., 2008) and increased algal bloom in Peri Lake, Brazil (Fuentes and Petricio, 2015). Phytoplankton density was found higher after monsoon season, between the month of January to April, which corresponded to increase in DO and $\mathrm{pH}$ levels in lake after monsoon (Golder and Chattopadhyay, 2016). The presence and abundance of Cryptophyta in Bera Lake require further investigation, however, as it was not reported earlier in this natural lentic system.
In Durian Tunggal, Euglenophyta and Chlorophyta were dominant groups during dry and wet season, respectively, whilst in Bukit Merah Reservoir, Chlorophyta was dominant group during both dry and wet seasons. A marked decrease in the density of euglenophytes and an increase in cryptophytes were observed during dry season. Trachelomonas spp., Ankistrodesmus falcatus and Scenedesmus sp. were the most dominant species in Durian Tunggal Reservoir. Euglenophytes were reported to occur predominantly in organically rich fresh waters (Likens, 2010); the higher density of phytoplankton in Durian Tunggal was probably related to high ammonium concentrations. Ammonia is known to be the dominant source of nitrogen for the growth of euglenoids (Wetzel, 2001).

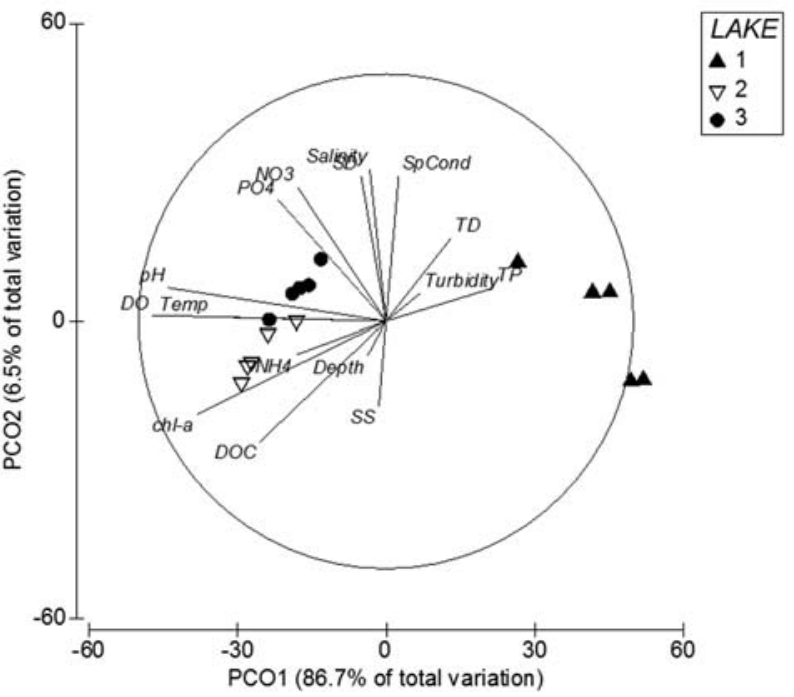

Fig. 5 : NMDS and PCoA biplots of zooplankton assemblages in lacustrine zones. Number indicates lake; 1 - Bera, 2 - Bukit Merah; 3 Durian Tunggal 

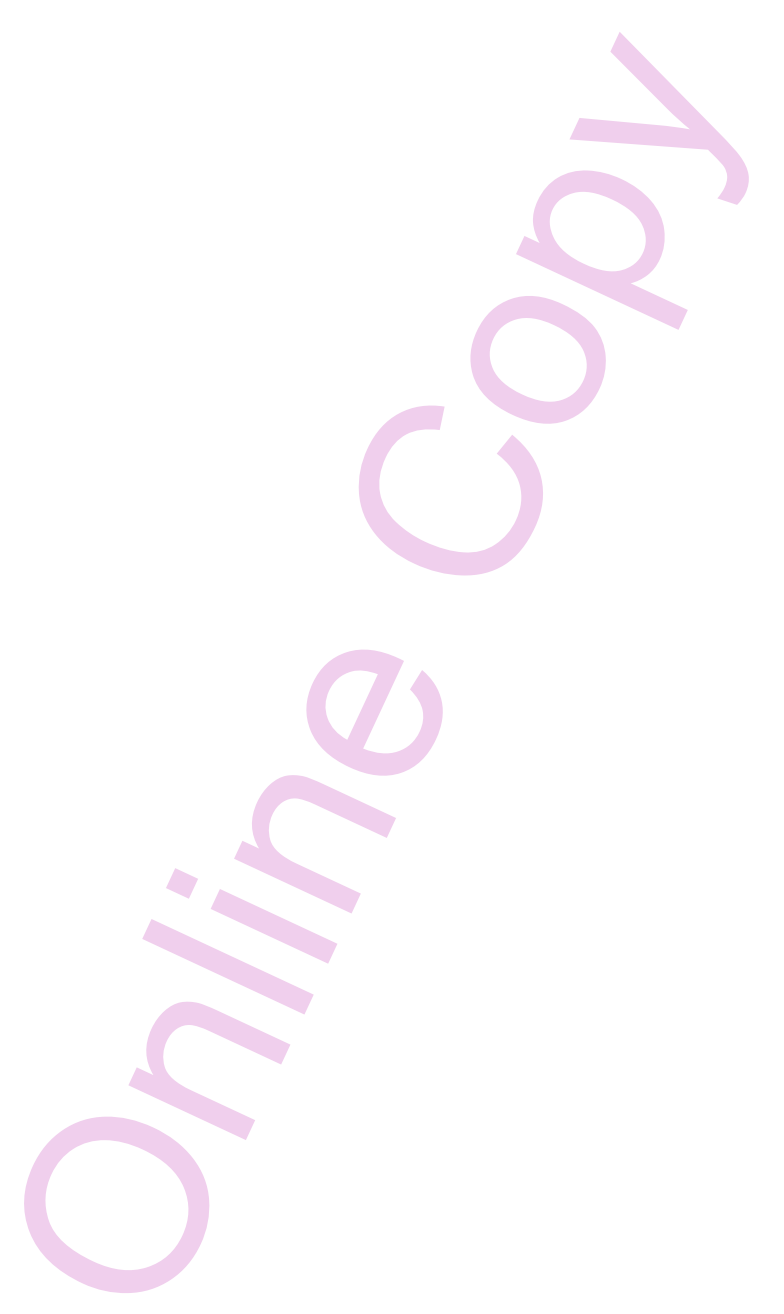
Table 2 : Results of PERMANOVA tests

\begin{tabular}{|c|c|c|c|c|c|}
\hline Source & df SS & MS & $\begin{array}{l}\text { Pseudo- } \\
\text { F }\end{array}$ & P-values & $\begin{array}{l}\text { Unique } \\
\text { permutations }\end{array}$ \\
\hline \multicolumn{6}{|l|}{ Phytoplankton } \\
\hline Lake & 213303 & 6651.4 & 23.039 & $0.003^{*}$ & 935 \\
\hline Depth (Lake) & $6 \quad 1755.4$ & 292.56 & 2.256 & 0.019 & \\
\hline Residual & 243111.4 & 129.64 & & & \\
\hline Total & 3219502 & & & & \\
\hline \multicolumn{6}{|l|}{ Zooplankton } \\
\hline Lake & 214669 & 334.7 & 42.621 & $0.001^{\text {** }}$ & 995 \\
\hline Residual & 122065.1 & 172.09 & & & \\
\hline Total & 1416735 & & & & \\
\hline
\end{tabular}

Note : ${ }^{*} P<0.05 ;{ }^{*} P \leq 0.001$

Straurastrum sp., Staurodesmus sp. and Ankistrodesmus sp. were the most dominant species in Bukit Merah reservoir. A higher abundance of cyanobacteria in Bukit Merah was consistent with the findings in eutrophic systems that documented high dominance of filamentous and large-colony forming cyanophytes such as Anabaenopsis spp., Planktothrix spp. and Anabaena spp. in the eutrophic Lake Aranchio due to nutrient availability and modulation in light environment (NaselliFlores and Barone, 2000). This study found higher phytoplankton densities in the man-made Bukit Merah reservoir compared to the natural Bera lake, probably due to the higher nutrient concentrations in the former. Mean phytoplankton density in Bera Lake and in the Durian Tunggal and Bukit Merah reservoirs were 295.6 cells $\mathrm{ml}^{-1}, 1381.7$ cells $\mathrm{ml}^{-1}$ and $13,388.2$ cells $\mathrm{ml}^{-1}$, respectively

Two-dimensional NMDS plots indicated phytoplankton assemblages (Fig 4) and zooplankton assemblages (Fig.5) in the natural Bera lake were distinctly separated from the phytoplankton and zooplankton assemblages in the man-made lakes. PERMANOVA results concerning lakes indicated significant variability in phytoplankton and zooplankton abundance between lakes (Table 2, P<0.05). However, variability in phytoplankton abundance was also significant at depth scale. $\mathrm{PCoA}$ results indicated that phytoplankton communities in Bera lake was positively correlated to DOC and negatively correlated to DO. Phytoplankton communities in Durian Tunggal tended to characterize lakes having clear water with low turbidity and TSS, and they were positively correlated to conductivity. Phytoplankton assemblages in Bukit Merah were positively correlated to Chla, DO and DOC. Zooplankton assemblages in the natural lake were positively correlated to turbidity and negatively correlated to DO, while zooplankton assemblages in two man-made lakes were associated to nutrients.

In Bera Lake, a lower phytoplankton density, consistent with low Chla values, was probably due to lower $\mathrm{pH}$ levels and higher turbidity that reduced light penetration. Depth, which influences the underwater light regime, is also an important factor for shaping phytoplankton abundance. Additionally, Bera lake has massive stands of macrophytes that could inhibit phytoplankton growth through competition of nutrients (Kosten et al., 2012) or allelopathic mechanism (Mulderij et al., 2005). Asma' et al. (2014) reported that phytoplankton in the littoral zone of a tropical manmade lake was significantly lower compared to limnetic zone.

In Bukit Merah Reservoir, chlorophytes were the most dominant phytoplankton group. A marked increase in cyanobacteria density was likely due to the lower $\mathrm{N}: \mathrm{P}$ ratio, probably resulting from a lower water level and subsequent reduction in external nutrient inputs (Noges et al., 2003; Haldna et al., 2008). Qualitative observation indicated the presence of patches of greenish-coloured waters in certain part of lake. Phytoplankton density was greater at surface layer and decreased alongside depth, consistent with the findings in Shingu Reservoir, Korea where phytoplankton community varied strongly with depth; highest abundance was observed in the surface layer (Kwon et al. 2009). The growth of many phytoplankton species was reported to be controlled by light intensity (Naselli-Flores and Barone, 2000) when other growth factors such as nutrients were not limiting. A marked increase in turbidity was likely due to the sediment re-suspension, which has previously been suggested as commonly occurring in this large reservoir (Sharip and Zaki, 2014) and which could affect light availability. In other shallow lakes such as Liman Lake in India, intense mixing promoted the dominance of low light tolerant phytoplankton species (Soylu and Gonulol, 2010).

T-test analysis indicated that differences in phytoplankton between natural Bera Lake and man-made Bukit Merah Lake were significant in terms of Bacillariophyceae and Chlorophyta, Euglenophyta and Cryptophyta $(P<0.05)$. SIMPER analysis indicated that the average dissimilarity of phytoplankton assemblages between Bera and Bukit Merah Lake was 50.1\%. Average dissimilarities in phytoplankton assemblages between surface-mid depth, surface-bottom and mid-bottom depth were $16.6 \%, 19.4 \%$ and $12.6 \%$, respectively. T-test analysis indicated that differences in phytoplankton between shallower Bukit Merah Lake and deeper Durian Tunggal Reservoir were significant in terms of Chlorophyta, Euglenophyta, Chrysophyta and andBacillariophyceae $(P<0.05)$. SIMPER analysis indicated that the average dissimilarity in phytoplankton assemblages between Bukit Merah and Durian Tunggal was 28.1\%. Average dissimilarities in phytoplankton assemblages between surfacemid-depth, surface-bottom and mid-bottom depth were $12.8 \%$, $21.2 \%$ and $16.7 \%$ respectively.

In Bera Lake, rotifer was the dominant zooplankton group during both dry and wet seasons (Fig. 6). Dominant rotifer species were Philodina sp., Lecane sp. and Arcella sp. A marked increase in copepods was observed during dry spell compared to wet period. In Durian Tunggal, rotifers and copepods were the dominant groups during dry and wet seasons, respectively, whilst in Bukit Merah Reservoir rotifers were the dominant group during both dry and wet seasons. Polyarthra sp., Keratella sp., and Hexarthra sp. were the most dominant species in Durian Tunggal reservoir. Difflugia sp. and Polyarthra sp. were the 
most dominant species in Bukit Merah reservoir. A significant increase in cladocerans and a decrease in rotifers were observed during dry spell compared to wet period. Mean zooplankton density was lowest in Bera Lake (18.3 ind. $\mathrm{ml}^{-1}$ ), followed by Durian Tunggal (800.2 ind. $\mathrm{ml}^{-1}$ ) and Bukit Merah (950.0 ind. $\mathrm{ml}^{-1}$ ). Seasonal changes of water level and abiotic factors regulated zooplankton dynamics in floodplain lake, Laguna Grande in Argentina, with shift from rotifers to cladocerans in cold seasons (Chaparro et al., 2016).

This study found higher zooplankton densities in both man-made lakes compared to the natural lake, probably due to higher phytoplankton densities in the former. Higher zooplankton density in the man-made Bukit Merah compared to the natural Bera Lake indicated that the establishment of zooplankton communities in this reservoir might be associated with environmental factors rather than lake age. Similar observation on the effects of human activities and lake age on zooplankton species richness was reported by Dodson et al., (2007) in their study on 3 to 9500-years-old lakes. The results of the present study indicate that water chemistry has greater effects on the biological community in the older lake (Bukit Merah) than the new ones (Durian Tunggal).

Marked changes in zooplankton assemblages were observed in Durian Tunggal Reservoir between the sampling periods. A significant decrease in rotifersmight be associated with an increase in salinity and conductivity, which decreased rotifer diversity. Salinity increase has been found to affect the change in terms of species richness and diversity of rotifer (Sarma et al., 2006; Bielanska-Grajner and Cudak, 2014). High turbidity and predation pressure at low waters can also decrease the zooplankton abundance. High turbidity reduces phytoplankton populations and subsequently results in a shift in food resources for zooplankton. These patterns may explain the variation found in three different tropical lakes included in this study. SIMPER analysis indicated that the average dissimilarity between Bera and Bukit Merah Lake was $66.4 \%$. Rotifer and copepod contributed $41.8 \%$ and $32.6 \%$, respectively, of the overall dissimilarity in zooplankton group. SIMPER analysis indicated that the average dissimilarity between Bukit Merah Lake and Durian Tunggal was 10.5\%. Cladocerans and copepods contributed $77.8 \%$ of the overall dissimilarity in zooplankton group.

The results of the present study indicates variations among phytoplankton and zooplankton assemblages in all three lake ecosystems. The management of tropical lakes needs to consider the unique characteristics of plankton assemblages and variations in water quality, which subsequently alters phytoplankton and zooplankton abundance. Development of algal dominance might differ amongst lakes, subsequently requiring different control and management measures. Further, the study reveals that cyanobacterial bloom might be a concern in Bukit Merah Reservoir during prolonged draughts. Since water intake station is tapping water of this reservoir downstream, additional measures may need to be undertaken in the station for utilizing the water during dry periods.

\section{Acknowledgments}

This research was supported by the Ministry of Science and Technology of Malaysia, e-Science Fund grant (No. 04-0309-SF0003). The authors are thankful to DID Kerian District, Perhilitan RAMSAR Tasek Bera and Syarikat Air Melaka Berhad for allowing us to conduct the research at field. Special thanks to Juhaimi Jusoh, Rahimah Abdullah, Aminuddin Jamin, Saim Suratman and Ahmad Jamalluddin Shaaban for their support in this project. We are grateful to Ahmad Taqiyuddin Ahmad Zaki, Mohd. Azril Hilmi Shapai, Mohd. Shukri Abu Bakar, Kamasuahadi Yasin, Nizam and Shukor for their aid in sampling assistance and Perumal Kuppan for his help in enumerating the plankton samples.

\section{References}

Alfonso, G., G. Belmonte, F. Marrone and L. Naselli-Flores: Does lake age affect zooplankton diversity in Mediterranean lakes and reservoirs? A case study from southern Italy. Hydrobiologia, 653, 149-164 (2010).

Anderson, M.J. and T.J. Willis: Canonical analysis of principal coordinates: Auseful method of constrained ordination for ecology. Ecology, 84, 511-525(2003).

Asthma, J., F.M. Yusoff, S. Banerjee and M. Shariff: Littoral and limnetic phytoplankton distribution and biodiversity in a tropical man-made lake, Malaysia. Adv. Stud. Biol., 6, 149-168 (2014).

APHA: Standard Methods for examination of water and wastewater. $22^{\text {nd }}$ Edn., APHA, AWWA, WPCF, Washington DC, USA(2012).

Barone, R. and L. Flores: Phytoplankton dynamics in a shallow, hypertrophic reservoir (Lake Arancio, Sicily). Hydrobiologia, 289, 199-214 (1994).

Bielanska-Grajner, I. and A. Cudak : Effects of salinity on species diversity of rotifers in anthropogenic water bodies. Pol. J Environ. Stud., 23 : 27-34 (2014).

Chaparro, G., M.S. Fontanarrosa and I. O'Farrell: Colonization and succession of zooplankton after a drought: Influence of hydrology and free-floating plant dynamics in a floodplain lake. Wetlands, 36, 85-100 (2016).

De Bie, T., S. Declerck, K. Martens, L. De Meester and L. Brendonck: A comparative analysis of cladoceran communities from different water body types : Patterns in community composition and diversity. Hydrobiologia, 597, 19-27 (2008).

Dodson, S., W. Everhart, A. Jandl and S.Krauskopf: Effect of watershed land use and lake age on zooplankton species richness. Hydrobiologia, 579, 393-399 (2007).

Dodson, S.I., A.L. Newman, S. Will-Wolf, M.L. Alexander, W.P. Woodford and S.Van Egeren : The relationship between zooplankton community structure and lake characteristics in temperate lakes (Northern Wisconsin, USA). J. Plankton Res., 31, 93-100 (2009).

Fuentes, E.V. and M.M. Petrucio: Water level decrease and increased water stability promotes phytoplankton growth in a mesotrophic subtropical lake. Mar. Freshw. Res., 66, 711-718 (2015)

Furtado, J.I. and S. Mori : The ecology of a tropical freshwater swamp, the Tasek Bera, Malaysia. DrW. Junk Publishers, The Hague (1982).

Golder, D. and S. Chattopadhyay: Interrelationship between physicochemical characteristics of a tropical lake and their impact on 
biodiversity of planktons. J. Environ. Biol., 37, 1281 (2016).

Haldna, M., A. Milius, R. Laugaste and K.I. Kangur : Nutrients and phytoplankton in Lake Peipsi during two periods that differed in water level and temperature. Hydrobiologia, 599, 3-11 (2008).

Kosten, S., M. Vernooij, E. Vannes, M. Adelosa, G. Sagrario, J.G.P.W. Clevers and M. Scheffer : Bimodal transparency as an indicator for alternative states in South American lakes. Freshw. Biol., 57, 11911201 (2012).

Kwon, Y., S. Hwang, K. Park, H. Kim, B. Kim, K. Shin, K. An, Y. Song and Y. Park : Temporal changes of phytoplankton community at different depths of a shallow hypertrophic reservoir in relation to environmental variables. Annales de Limnologie- Int. J. Limnol., 45, 93-105 (2009).

Likens, G.E.: Plankton of inland waters : A derivative of encyclopedia of inland waters. Elsevier Inc., Milbrook (2010).

Mac Donagh, M.E, M.A. Casco and M.A. Claps : Plankton relationships under small water level fluctuations in a subtropical reservoir. Aquat. Ecol., 43, 371-381 (2009).

Valeriano-Riveros, M.E., G. Vilaclara, F. S. Castillo-Sandoval and M. Merino- Ibarra : Phytoplankton composition changes during water level fluctuations in a high-altitude, tropical reservoir. Inland Waters, 4, 337-348 (2014).

Merrix-Jones, F.L., S.J. Thackeray and S.J. Ormerod : A global analysis of zooplankton in natural and artificial fresh waters. J. Limnol., 72, 140-153 (2013).

Morley, R.J. : The palaeoecology of Tasek Bera, a lowland swamp in Pahang, West Malaysia. Singapore J. Trop. Geography, 2, 49-56 (1981).

Mulderij, G., W.M. Mooij, A.J.P. Smolders and E. Van Donk. : Allelopathic inhibition of phytoplankton by exudates from Stratiotes aloides. Aquat. Bot., 82, 284-296 (2005).

Naselli-Flores, L. and R. Barone: Phytoplankton dynamics and structure: A comparative analysis in natural and man-made water bodies of different trophic state. Hydrobiologia, 438, 65-74 (2000).

Noges, T., P. Noges and R. Laugaste : Water level as the mediator between climate change and phytoplankton composition in a large shallow temperate lake. Hydrobiologia, 506, 257-263 (2003).

Reynolds, C.S. : What factors influence the species composition of phytoplankton in lakes of different trophic status? Hydrobiologia, 369, 11-26 (1998).

Sarma, S.S.S., S. Nandini, J.S. Morales-Ventura, I. Delgado-Martanez and L. Gonzalez-Valverde: Effects of $\mathrm{NaCl}$ salinity on the population dynamics of freshwater zooplankton (rotifers and cladocerans). Aquat. Ecol., 40, 349-360 (2006).

Sharip, Z. and A.T.A Zaki : The effects of season and sand mining activities on thermal regime and water quality in a large shallow tropical lake. Environ. Monit. Assess.,186, 4959-4969 (2014).

Sharip Z., S.S. Schooler, M.R. Hipsey and R.J. Hobbs: Eutrophication, agriculture and water level control shift aquatic plant communities from floating-leaved to submerged macrophytes in Lake Chini, Malaysia. Biol. Inv., 14, 1029-1044 (2012).

Soylu, E.N. and A. Gonulol: Seasonal succession and diversity of phytoplankton in a eutrophic lagoon (Liman Lake). J. Environ. Biol., 31, 629-636 (2010).

Wetzel, R.G.: Limnology: Lake and river ecosystems. Academic Press, San Diego (2001). 